\title{
Cytogenetic studies in fishes of the genera Hassar, Platydoras and Opsodoras (Doradidae, Siluriformes) from Jarí and Xingú Rivers, Brazil
}

\author{
Susana Suely Rodrigues Milhomem ${ }^{1}$, Augusto Cesar Paes de Souza ${ }^{1}$, Aline Lira do Nascimento ${ }^{1}$, \\ Jaime Ribeiro Carvalho Jr. ${ }^{3}$, Eliana Feldberg ${ }^{2}$, Julio Cesar Pieczarka ${ }^{1}$ and Cleusa Yoshiko Nagamachi ${ }^{1}$ \\ ${ }^{1}$ Departamento de Genética, Universidade Federal do Pará, Belém, Pará, Brazil. \\ ${ }^{2}$ Instituto Nacional de Pesquisas da Amazônia, Manaus, AM, Brazil. \\ ${ }^{3}$ Centro Jovem de Aquaculturismo, Belém, Pará, Brazil.
}

\begin{abstract}
We studied the karyotypes of Hassar cf. orestis and an undescribed Hassar species from the Jarí River and Opsodoras ternetzi, H. orestis and Platydoras cf. costatus from the Xingú River, all with $2 n=58$. Constitutive heterochromatin is located in the centromere in most metacentric pairs; in some chromosomes this banding is not present, or it is located on the whole chromosome arm or in the distal regions. The NOR is located on a single biarmed pair at a distal region of the short arm in $\mathrm{H}$. cf. orestis, $\mathrm{H}$. orestis and $P$. cf. costatus at a distal region of the long arm in $O$. ternetzi and at a proximal region of the long arm in the Hassar species. In all species (except for Hassarsp.) the CMA3 analysis revealed a rich G-C region coincident with the NOR. Probably inversions occurred in the NOR chromosome during the chromosomal differentiation of the Doradidae species here described.
\end{abstract}

Key words: chromosomes, Amazon, biodiversity, Siluriformes, banding, fluorochromes.

Accepted: August 28, 2006; Received: June 8, 2007.

The species of the Doradidae family are usually known as thorny catfishes. They are distributed throughout all the main river systems in the American continent (Higushi, 1992). In South America, these fishes can be found in a large range of freshwaters habitats, between the parallels $10^{\circ} \mathrm{N}$ and $35^{\circ} \mathrm{S}$. Approximately 80 species are described from the Orinoco, Essequibo, Putumayo, Napo, Ucayali-Marañon, Amazonas and its tributaries (Negro, Madeira and Xingú), Tocantins-Araguaia and ParaguayParaná River systems. Some endemic species can be found in the São Francisco-Velhas River system in central eastern Brazil with two primitive forms limited to the Jequitinhonha and Paraguaçu River system (Higushi, 1992; de Pinna, 1998).

The fishes from this family have a size range from three centimeters to one meter. They are easily identified by the series of bony plates on each side of the body, where each plate has a curved torn of different size, depending on the species. Some have additional plates among the dorsal and adipose fins, or even covering most of the body. They are omnivorous fishes (Ferreira et al., 1998) and are also called talking catfishes because they are able to make

Send correspondence to Cleusa Yoshiko Nagamachi. Departamento de Genética, Universidade Federal do Pará, Campus do Guamá, Av. Augusto Corrêa, sn., CCB, $3^{\circ}$ andar, 66075-900 Belém, PA, Brazil. E-mail: cleusa@ufpa.br. sounds by movements of the pectoral spine or as vibrations produced by the swim bladder (Nelson, 1994).

Based on the cladistic methodology applied for osteological traits, Higuchi (1992) divided this family of 70 species into 33 genera, where three were new. Nelson (1994) reports that the family Doradidae has around of 35 genera with 90 species. Sabaj and Ferraris Jr. (2003) recognized 72 valid species in 30 genera. Following this review, Moyer et al. (2004) provide a genus-level phylogeny for doradids based on mitochondrial (12S and 16S rRNA) and nuclear (elongation factor- 1 alpha EF1 $\alpha$ ) gene sequences, as well as a re-evaluation of published morphological data. This phylogeny differs in some aspects from the one proposed by Higuchi (1992).

Few species have their karyotypes studied (Fenocchio et al., 1993; Venere, 1998; Eler et al., 2007). These data show that, even with few species cytogenetically studied in this family, a large variation among the karyotypes is evident, especially in chromosomes morphology (Table 1). In the present paper we describe the karyotypes of Hassar cf. orestis, Hassar sp., Hassar orestis Burgess, 1989, Opsodoras ternetzi Eigenmann, 1925 and Platydoras cf. costatus Linnaeus, 1758 aiming to contribute to their taxonomic classification and a better understanding of their chromosomal evolution. 
Table 1 - Chromosomal characterization of the family Doradidae. $2 \mathrm{n}=$ diploid number; FN = Fundamental Number; KF $=$ Karyotypic formulae; $\mathrm{NOR}=$ Nucleolar Organizer Region; $\mathrm{M}=$ metacentric; $\mathrm{SM}=$ submetacentric; $\mathrm{ST}=$ subtelocentric; $\mathrm{A}=$ acrocentric; $\mathrm{p}=$ short arm; $\mathrm{q}=$ long arm. $\mathrm{M}=\mathrm{male}$; $\mathrm{F}=$ female.

\begin{tabular}{|c|c|c|c|c|c|}
\hline Species & $2 n$ & $\mathrm{FN}$ & $\mathrm{KF}$ & NOR & Reference \\
\hline Hassar cf. orestis & 58 & 116 & $32 \mathrm{M}+18 \mathrm{SM}+8 \mathrm{ST}$ & $20^{\circ} \mathrm{SM}, \mathrm{p}$, distal & Present paper \\
\hline Hassar orestis & 58 & 114 & $42 \mathrm{M}+14 \mathrm{SM}+2 \mathrm{~A}$ & $\mathrm{SM}, \mathrm{q}$, distal & Venere (1992) \\
\hline Hassar orestis & 58 & 116 & $32 \mathrm{M}+20 \mathrm{SM}+6 \mathrm{ST}$ & $22^{\circ} \mathrm{SM}, \mathrm{p}$, distal & Present paper \\
\hline Hassar sp. & 58 & 116 & $32 \mathrm{M}+18 \mathrm{SM}+8 \mathrm{ST}$ & $7^{\circ} \mathrm{M}, \mathrm{q}$, proximal & Present paper \\
\hline Hassar wilderi & 58 & 116 & $32 \mathrm{M}+16 \mathrm{SM}+10 \mathrm{ST}$ & $\mathrm{SM}, \mathrm{p}$, distal & Venere (1992) \\
\hline Leptodoras acipenserinus & 58 & 112 & $24 \mathrm{M}+16 \mathrm{SM}+14 \mathrm{ST}+4 \mathrm{~A}$ & $\mathrm{ST}, \mathrm{p}$, distal & Venere (19992) \\
\hline Opsodoras sp. & 58 & $\begin{array}{l}109 \mathrm{~F} \\
108 \mathrm{M}\end{array}$ & $\begin{array}{l}21 \mathrm{M}+18 \mathrm{SM}+12 \mathrm{ST}+7 \mathrm{~A} \\
20 \mathrm{M}+18 \mathrm{SM}+12 \mathrm{ST}+8 \mathrm{~A}\end{array}$ & $\mathrm{SM}, \mathrm{p}$, distal & Venere (1992) \\
\hline Opsodoras ternetzi & 58 & 114 & $44 \mathrm{M}+12 \mathrm{SM}+2 \mathrm{~A}$ & $24^{\circ} \mathrm{SM}, \mathrm{q}$, distal & Present paper \\
\hline Platydoras cf. costatus & 58 & 104 & $26 \mathrm{M}+16 \mathrm{SM}+4 \mathrm{ST}+12 \mathrm{~A}$ & $20^{\circ} \mathrm{SM}, \mathrm{p}$, distal & Present paper \\
\hline Pseudodoras niger & 58 & 102 & $20 \mathrm{M}+16 \mathrm{SM}+8 \mathrm{ST}+14 \mathrm{~A}$ & $15^{\circ} \mathrm{SM}, \mathrm{p}$, distal & Fenocchio et al. (1993) \\
\hline Rhynodoras d'orbignyi & 58 & 102 & $20 \mathrm{M}+20 \mathrm{SM}+4 \mathrm{ST}+14 \mathrm{~A}$ & $16^{\circ} \mathrm{SM}, \mathrm{p}$, distal & Fenocchio et al. (1993) \\
\hline Rhynodoras sp. & 58 & 104 & $18 \mathrm{M}+16 \mathrm{SM}+12 \mathrm{ST}+12 \mathrm{~A}$ & $\mathrm{SM}, \mathrm{p}$, distal & Venere (1992) \\
\hline Trachydoras paraguaiensis & 56 & 112 & $32 \mathrm{M}+20 \mathrm{SM}+4 \mathrm{ST}$ & SM, q, interstitial & Fenocchio et al. (1993) \\
\hline Wertheimeria maculata & 58 & 104 & $24 \mathrm{M}+14 \mathrm{SM}+8 \mathrm{ST}+12 \mathrm{~A}$ & $\mathrm{M}, \mathrm{p}$, distal & Eler et al. (2007) \\
\hline Hassar wilderi & 58 & 116 & $32 \mathrm{M}+16 \mathrm{SM}+10 \mathrm{ST}$ & $\mathrm{ST}, \mathrm{p}$, distal & Eler et al. (2007) \\
\hline
\end{tabular}

We analyzed fishes of the family Doradidae, from Rivers Jarí (PA) and Xingú (PA). From Jarí River $\left(\mathrm{S}=03^{\circ}\right.$ $18^{\prime} 14,9^{\prime \prime}$ and $\left.\mathrm{W}=52^{\circ} 03^{\prime} 29,3^{\prime \prime}\right)$ three females and two males of the Hassar cf. orestis species were analyzed as well as three females of the species Hassar sp. From Xingú River ( $\mathrm{S}=02^{\circ} 37^{\prime} 44,3^{\prime \prime}$ and $\left.\mathrm{W}=51^{\circ} 57^{\prime} 06,4^{\prime \prime}\right)$, three females and two males of the Opsodoras ternetzi species were analyzed as well as one male and one female of the species Hassar orestis. Also from this River $\left(\mathrm{S}=03^{\circ} 50^{\prime}\right.$ $46,6^{\prime \prime}$ and $\mathrm{W}=52^{\circ} 29^{\prime} 22,3^{\prime \prime}$ ) four females of the species Platydoras cf. costatus were analyzed. Voucher specimens were deposited in the fish collection of the Museu Paraense Emilio Goeldi in Belém, Pará, Brazil: Hassar orestis (MPEG 12463) and Opsodoras ternetzi (MPEG 12464), both from Xingú River. The other specimens here described remain uncatalogued.

Mitotic chromosome preparations were obtained from kidney cells using the air-drying technique of Bertollo et al. (1978). C-banding (Sumner, 1972), Ag-NOR staining (Howell and Black, 1980) and Chromomycin A3 $\left(\mathrm{CMA}_{3}\right)$ banding (Schweizer, 1980) were applied. Chromosome morphology was determined on the basis of arm ratio as proposed by Guerra (1986), and chromosomes were classified as metacentrics $(\mathrm{M})$, submetacentrics (SM), subtelocentrics (ST) and acrocentrics (A).

The five species here studied have $2 \mathrm{n}=58$ chromosomes. Hassar cf. orestis (Figure 1a) and Hassar sp. (Figure $1 \mathrm{~b}$ ) have $32 \mathrm{M}+18 \mathrm{SM}+8 \mathrm{ST}$ and $\mathrm{FN}=116$ Opsodoras ternetzi (Figure 1c) has $44 \mathrm{M}+12 \mathrm{SM}+2 \mathrm{~A}$ and $\mathrm{FN}=114$, Hassar orestis (Figure 1d) has $32 \mathrm{M}+20 \mathrm{SM}+6 \mathrm{ST}$ and
$\mathrm{FN}=116$, and Platydoras $\mathrm{cf}$. costatus (Figure 1e) has $26 \mathrm{M}+16 \mathrm{SM}+4 \mathrm{ST}+12 \mathrm{~A}$ and $\mathrm{FN}=104$. None of these species has shown any sex chromosome heteromorphism.

Single Ag-NORs were observed in all species. In Hassar cf. orestis (Figure 1a) from Jarí River, and in Hassar orestis (Figure 1d) and Platydoras cf. costatus (Figure 1e) from Xingú River the NOR is located at a distal position of the short arm, while in Hassar sp. (Figure 1b) it is at interstitial position of the long arm and in Opsodoras ternetzi (Figure 1c) it locates to a distal position of the long arm on submetacentric chromosomes.

Constitutive heterochromatin could be found in the centromeric region of most of metacentric chromosomes, showing a faint banding pattern in all the species here studied. It was possible also to find heterochromatic blocks in the short arms of Hassar orestis (Figure 2d) and Opsodoras ternetzi (Figure 2c). $\mathrm{CMA}_{3}$ banding in the species Hassar cf. orestis (Figure 2a), Opsodoras ternetzi (Figure 2c), Hassar orestis (Figure 2d) and Platydoras cf. costatus (Figure 2e) showed regions rich in G-C base pairs coincident with the NOR location. Unfortunately, it was not possible to do this banding in Hassar sp.

Table 1 summarizes the karyotype data obtained in the present study and those available in the literature. When we compare the results here obtained with the ones described by Venere (1998) we can note that there is good agreement on the diploid number in the genus Hassar, except for a small difference in the fundamental number of Hassar oresti, because the karyotype described by that author has one acrocentric pair which is not present in the 


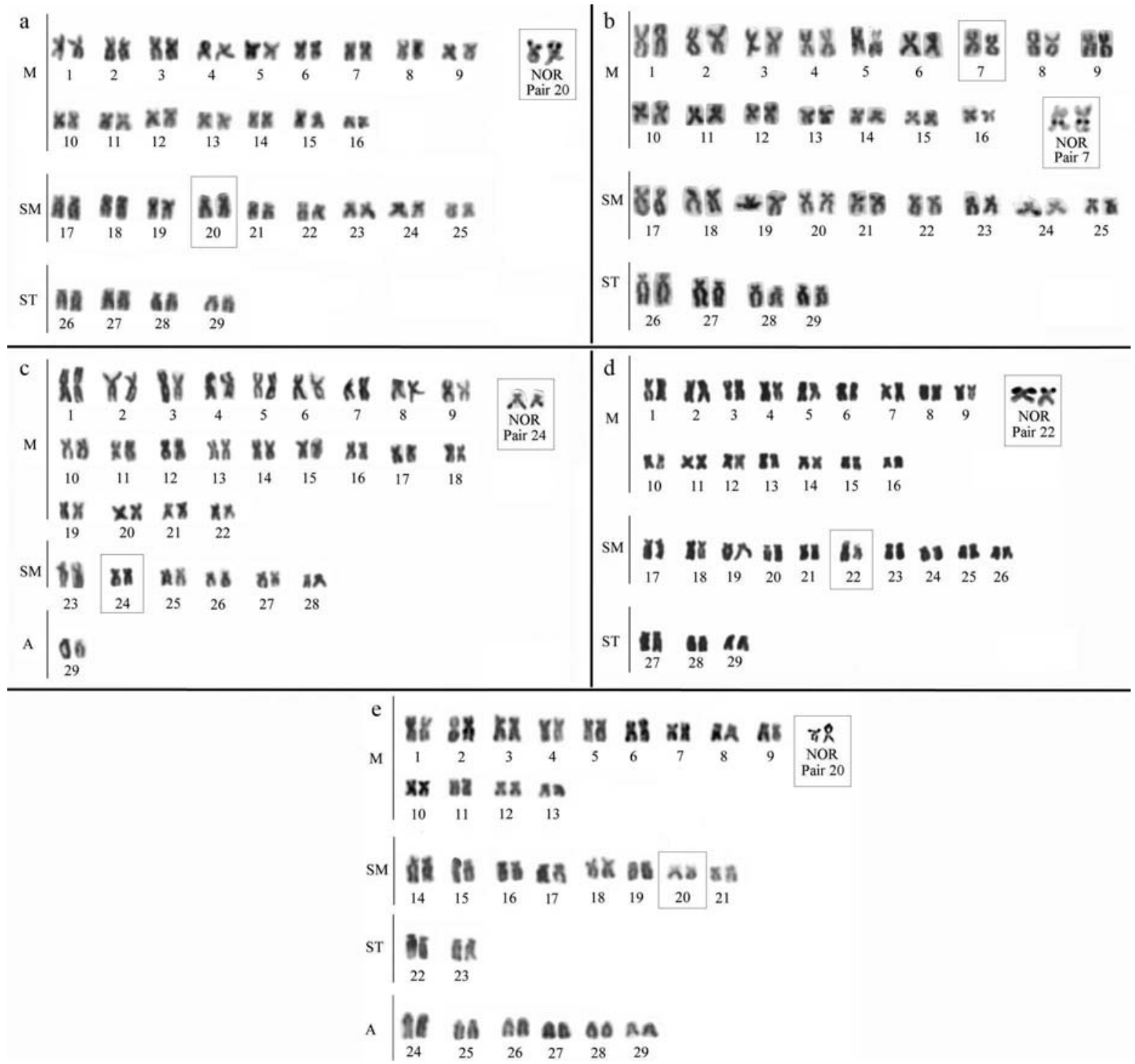

Figure 1 - Giemsa stained karyotypes of the species: a) Hassar cf. orestis; b) Hassar sp.; c) Opsodoras ternetzi; d) Hassar orestis; e) Platydoras cf. costatus. Within the boxes are the NOR-stained chromosomes of each species.

karyotype here described. The species Opsodoras ternetzi here described also has the same diploid number, however, the karyotype is different from the species Opsodoras sp. (Venere, 1998) because it does not have sex chromosome heteromorphism or acrocentric pairs.

The family Doradidae has around of 80 species (de Pinna, 1998), from which 14 were already karyotyped and most have $2 n=58$. Probably this is the modal diploid number of this family, the same diploid number which is also considered ancestral for Siluriformes (Oliveira et al., 1988). Eler et al. (2007) described the karyotype of Wertheimeria maculata, which according to Higushi (1992) is a sister taxon of all Doradidae. This species has $2 \mathrm{n}=58$ $(24 \mathrm{M}+14 \mathrm{SM}+8 \mathrm{ST}+12 \mathrm{~A})$, supportig the hypothesis that this diploid number is plesiomorphic for the Doradidae.

The C-banding pattern was similar for the entire group, with a heterochromatic faint pattern. Fenocchio and
Bertollo (1992) noted that it is very difficult to obtain good C-banding in Pimelodidae, a family phylogenetically related to Doradidae. This can best be explained by the peculiar traits of the chromatin of these fishes rather than by the absence of heterochromatic regions.

When looking at Hassar wilderi and Opsodoras sp. which were already analyzed using $\mathrm{CMA}_{3}$ banding (Venere, 1998), we can conclude that this G-C base pairs specific fluorochrome is useful for visualizing the NOR in fishes. According to Pendás et al. (1993), the positive correlation between NOR and $\mathrm{CMA}_{3}$ banding occurs because the rRNA genes from NOR region are interspersed by DNA sequences which are rich in G-C base pairs.

The single NOR in the distal position of a short arm in the species Hassar cf. orestis from Jarí River, Hassar orestis and Platydoras cf. costatus from Xingú River is similar to the one described for Hassar wilderi, Leptodoras 

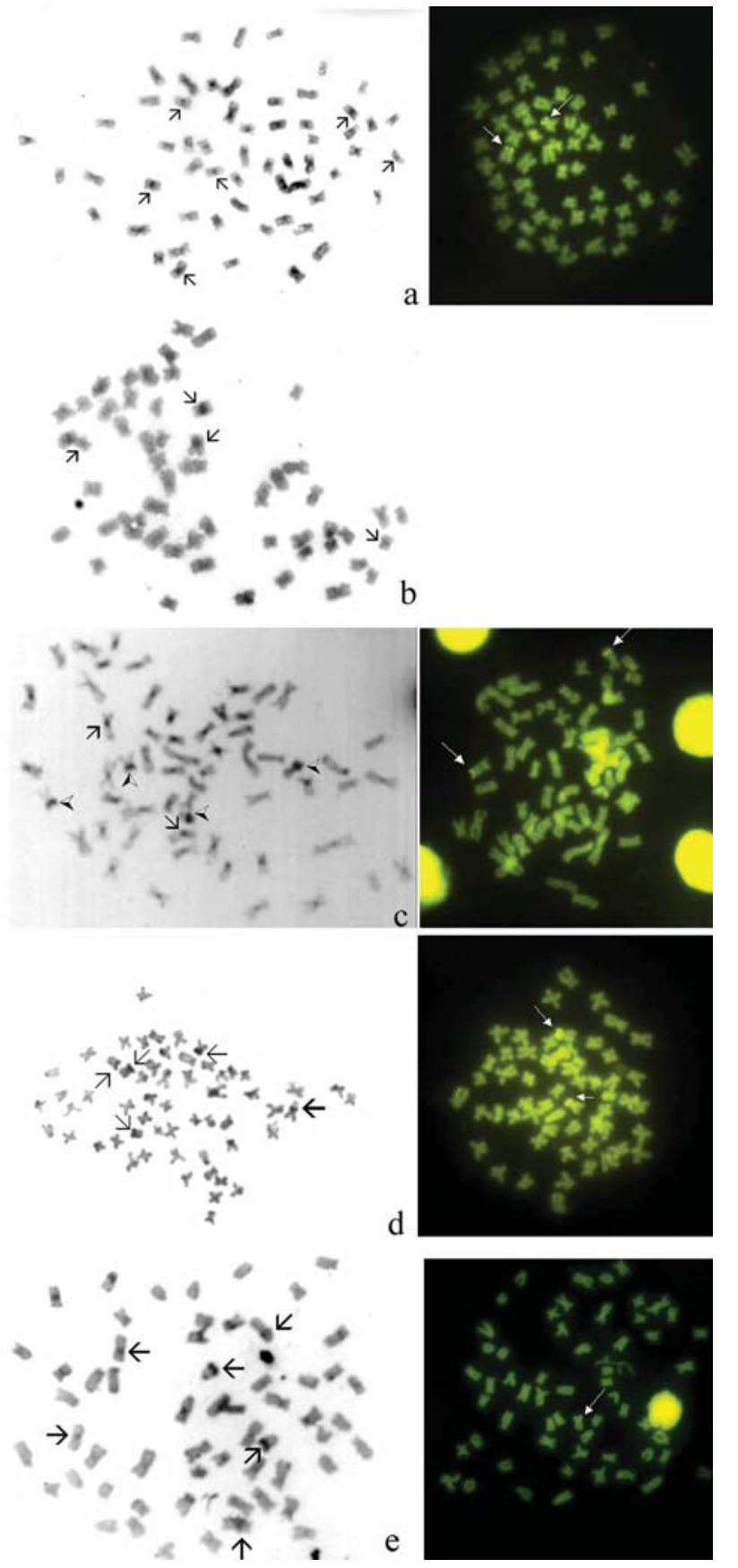

Figure 2 - C-banded (left) and $\mathrm{CMA}_{3}$ banded (right) karyotypes of the species: a) Hassar cf. orestis; b) Hassar sp.; c) Opsodoras ternetzi; d) Hassar orestis; e) Platydoras cf. costatus. In the C-banded karyotype shown in $2 \mathrm{c}$, the arrows point to centromeric heterochromatin, while the arrow heads show heterochromatic blocks in the short arms.

acipenserinus, Opsodoras sp. and Rhynodoras sp. (Venere, 1998), and also for Pseudodoras niger and Rhynodoras d'orbignyi (Fenocchio et al. 1993). In Hassar sp. from Jarí, the NOR is similar to the one in Trachydoras paraguaiensis (Fenocchio et al. 1993) since both are located in an interstitial region in the long arm of a submetacentric pair. In Opsodoras ternetzi from Xingú the NOR is located at the distal region of the long arm of a submetacentric chromosome pair same as in Hassar orestis (Venere, 1998).

The results here obtained for the species Hassar orestis from Jarí and Xingú Rivers show that the NOR is located in the distal region of the short arm. One chromosome pair with heterochromatic blocks in the short arms in Hassar orestis (Figure 2d) from Xingú River is probably the NOR bearer chromosome, showing a more evident secondary constriction in one copy of the pair which seems to be a species-specific marker. Venere (1998) studied the same species from Araguaia River and found the NOR in the distal region of the long arm. These results are important since they show the possibility of using the NOR as a population marker.

If one accepts that the analyzed NOR bearer chromosomes in the genus Hassar are homologous, potential paracentric and/or pericentric inversions could have played a role in the karyotypic evolution of these species, moving the NOR to different places of the chromosomes. According to Almeida-Toledo (1998), NOR position changes can be an important marker for karyotypic differences among populations or species of fishes. The NOR size polymorphisms are very frequent in fishes and can be found also in mammals and other vertebrates and seems to be a general trait of NORs. This size polymorphism was observed in all the species here studied. Concerning the Opsodoras ternetzi we observed a difference in NOR position when compared with the Opsodoras sp. (Venere, 1998). In the first one the staining occurred in the distal region of the long arm of a metacentric pair, while in the latter the staining was in the distal region of the short arm of a subtelocentric pair. Apart from this, the modal number is conserved as in other species of this group, but the chromosome formulae and the fundamental numbers change with respect to $\mathrm{M}+\mathrm{SM}+\mathrm{ST}+\mathrm{A}$, suggesting that inversions can be involved not only in the NOR bearers but also in the differentiation of other chromosomal pairs.

According to Lundberg and Friel (2004), Auchenipteridae is the family that is most closely related to Doradidae. Souza et al. (2001) described the karyotypes of four species of this family, where three species have a single NOR located in a distal portion of a short arm, like Hassar cf. orestis from Jarí River, Hassar orestis and Platydoras cf. costatus from Xingú River here presented, as well as Hassar wilderi, Leptodoras acipenserinus, Opsodoras sp. and Rhynodoras sp. (Venere, 1998) and Pseudodoras niger and Rhynodoras d'orbignyi (Fenocchio et al., 1993). The ancestral location of NORs may be in the distal portion of a short arm, since it is found in species from both Doradidae and Auchenipteridae. Cytogenetic research on other species of this family should help to define the phylogenetic relationships within this group, as well as the understanding of the chromosomal evolutionary mechanisms that acted in the chromosomal differentiation of these species. 


\section{Acknowledgments}

This work was supported by: SECTAM-FUNTEC, IBAMA, CNPq, CAPES, UFPA/PROPESP/PROINT and INPA.

\section{References}

Almeida-Toledo LF (1998) Cytogenetic markers in Neotropical freshwater fishes. In: Malabarba LR, Reis RE, Vari RP, Lucena ZMS and Lucena CAS (eds) Phylogeny and Classification of Neotropical Fishes. Edipucrs, Porto Alegre, pp 583-588.

Bertollo LAC, Takahashi CS and Moreira-Filho O (1978) Citotaxonomic considerations on Hoplias lacerdae (Pisces, Erythrinidae). Rev Bras Genet 2:103-120.

Eler ES, Dergam JA, Vênere PC, Paiva LC, Miranda GA and Oliveira AA (2007) The karyotypes of the thorny catfishes Wertheimeria maculata Steindachner, 1877 and Hassar wilderi Kindle, 1895 (Siluriformes, Doradidae) and their relevance in doradids chromosomal evolution. Genetica 130:99-103.

Fenocchio AS and Bertollo LAC (1992) Karyotype similarities among Pimelodidae (Pisces, Siluriformes) from the Brazilian Amazon region. Cytobios 69:41-46.

Fenocchio AS, Jorge LC, Venere PC and Bertollo LAC (1993) Karyotypic characterization and nucleolus organizer regions in three species of Doradidae (Pisces, Siluriformes). Rev Bras Genet 4:1097-1101.

Ferreira EJG, Zuanon JAS and Santos GM (1998) Peixes Comerciais do Médio Amazonas: Região de Santarém, Pará. IBAMA, Brasília, 214 pp.

Guerra MS (1986) Reviewing the chromosome nomenclature of Levan et al. Rev Bras Genet 4:741-743.

Higuchi H (1992) A phylogeny of the South American thorny catfishes (Osteichthyes, Siluriformes, Doradidae). PhD Thesis, Harvard University, Cambridge.

Howell WM and Black DA (1980) Controlled silver-staining of nucleolus organizer regions with a protective colloidal developer: A 1-step method. Experientia 36:1014-1015.
Lundberg JG and Friel JP (2003). Siluriformes. Catfishes, v. 20 January 2003 (under construction). http://tolweb.org/ Siluriformes/15065/2003.01.20. In: Tree of Life Web Project, http://tolweb.org/.

Moyer GR, Burr BM and Krajewski C (2004) Phylogenetic relationships of thorny catfishes (Siluriformes, Doradidae) inferred from molecular and morphological data. Zool J Linn Soc 140:551-575.

Nelson JS (1994) Fishes of the World. John Wiley and Sons, New York, 164 pp.

Oliveira C, Almeida-Toledo LF, Foresti F, Britski HA and Toledo Filho SA (1988) Chromosome formulae of Neotropical freshwater fishes. Rev Bras Genet 3:577-624.

Pendás AM, Morán P and García-Vázquez E (1993) Ribosomal RNA genes are interspersed throughout a heterochromatic chromosome arm in Atlantic Salmon. Cytogenet Cell Genet 63:28-130.

de Pinna MCC (1998) Phylogenetic relationships of Neotropical Siluriformes (Teleostei, Ostariophysi): Historical overview and synthesis of hypothesis. In: Malabarba LR, Reis RE, Vari RP, Lucena ZMS and Lucena CAS (eds). Phylogeny and Classification of Neotropical Fishes. Edipucrs, Porto Alegre, pp 279-330.

Sabaj MH and Ferraris Jr CJ (2003) Family Doradidae. In: Reis RE, Kullander SO and Ferraris Jr CJ (eds). Check list of the freshwater fishes of South and Central America. Edipucrs, Porto Alegre, pp 456-469.

Schweizer D (1980) Simultaneous fluorescent staining of R bands and specific heterochromatic regions (DA/DAPI bands) in human chromosomes. Cytogenet Cell Genet 27:190-193.

Souza EL, Feldberg E and Nakayama CM (2001) Estudos cromossômicos na família Auchenipteridae (Siluriformes) na área do Catalão, AM. In: Anais da X Jornada de Iniciação Científica de PIBIC/INPA, Manaus, pp 150-153.

Sumner AT (1972) A simple technique for demonstrating centromeric heterochromatin. Exp Cell Res 75:304-306.

Venere PC (1998) Diversificação cariotípica em peixes do médio rio Araguaia, com ênfase em Characiformes e Siluriformes (Teleostei, Ostariophysi). Ph.D. Thesis, Universidade Federal de São Carlos, São Carlos.

Associate Editor: Fausto Foresti 